\title{
Perception assessment of periodontal patients regarding their self-care
}

\author{
Avaliação da percepção dos pacientes periodontais em relação à importância do autocuidado
}

\author{
Athus GARCIA 1 \\ Érika Manuela Asteria CLAVIJO' \\ Flávia Martão FLÓRIO' \\ Luciana Satie OKAJIMA' \\ Almenara de Souza FONSECA-SILVA ${ }^{1}$
}

\section{ABSTRACT}

\section{Objective}

The aim of this study is to evaluate, through a questionnaire, patients' awareness and behavior regarding periodontal disease, as well as their perceptions of the importance of self-care in order to control the disease.

\section{Methods}

50 male and female patients, age ranging between 31 to 67 years old, presenting moderate to advanced periodontal disease were submitted to a 26 question-survey which aimed to assess the following: the patient's profile, his knowledge and awareness of the periodontal disease, the dental practioner's commitment as to inform the patient about the importance of the concepts and understandings of his own self-care related to the disease. After data tabulation, they were subjected to exploratory analysis by means of tables and graphics of distribution of frequencies.

\section{Results}

The data showed that most patients were unanimously aware of the presence of periodontal disease and it also demonstrated that if they follow the dentist's recommendations, there will be a better disease prognosis. About 94 to $96 \%$ of the participants in the sample showed a higher level of knowledge about the etiology, treatment and consequences of periodontal disease, and reported that such information came from dental professionals.

\section{Conclusion}

It was concluded that the periodontal disease patient becomes motivated to promote his self-care when the dentist promotes a proper instruction.

Indexing terms: Periodontal disease. Prevention \& Control. Self care.

\section{RESUMO}

\section{Objetivo}

Avaliar o conhecimento dos pacientes em relação à doença periodontal e o empenho do profissional em educar, assim como seu comportamento e percepção com relação à importância do autocuidado para controle da doença.

\section{Métodos}

A amostra foi composta por 50 pacientes portadores de doença periodontal, que estavam em tratamento nos cursos de pós-graduação em Periodontia da Faculdade de Odontologia São Leopoldo Mandic, pertencentes a ambos os gêneros e com idade variando de 31 a 67 anos. 0 instrumento da pesquisa foi um questionário composto por perguntas de múltiplas escolhas. Após digitação e tabulação dos dados em planilha eletrônica Excel, estes foram submetidos à análise exploratória, sendo analisados por meio de tabelas e gráficos de distribuição de freqüências.

\section{Resultados}

Os dados, com base nas declarações obtidas, demonstraram que a maioria dos pacientes em tratamento apresentou grande receptividade e dedicação quanto aos autocuidados para controle da doença periodontal. Verificou-se uma consciência unânime de que se seguirem as recomendações do cirurgião-dentista, haverá um melhor prognóstico para a enfermidade. Cerca de 94 a $96 \%$ dos participantes da amostra apresentaram bom nível de conhecimento quanto à etiologia, controle e conseqüências da doença periodontal, afirmando terem recebido tais informações dos profissionais.

\section{Conclusão}

Conclui-se que o paciente se torna motivado quanto aos autocuidados para controle da doença periodontal, quando o cirurgião-dentista promove uma adequada educação e motivação.

Termos de indexação: Doenças periodontais. Autocuidado. Prevenção \& Controle.

\footnotetext{
${ }^{1}$ Faculdade São Leopoldo Mandic, Curso de Odontologia. Rua José Rocha Junqueira, 13, Swift, 13045-755, Campinas, SP, Brasil. Correspondência para / Correspondence to: AS FONSECA-SILVA. E-mail: <asfsilva@terra.com.br>
} 


\section{INTRODUCTION}

Periodontal diseases can be a challenge to dental practioners and public health since they encompass the major cause of tooth loss in adults, causing a crucial impact both on patients' oral functions and appearance'.

Tooth loss, resulting from the disease, directly affects masticatory ability, causing feed impairing, aesthetics and speech damage as well as psychological alterations. Repercussions such as these, contribute to the reduction in the daily life quality when understood as a sign of social inequality².

Historically, Brazil has shown a faulty scenario concerning preventive and curative adult dental treatment, therefore triggering a raise in the number of edentulous patients. This could have certainly been avoided if proper treatment had been early instituted the high prevalence of periodontal disease in the Brazilian population is, indeed, one of the causes for this scenario.

The last epidemiological survey based on the Community Periodontal Index (CPI), according to macroregions and age groups in the country, show that $53.8 \%$ of people aged 15-19 years old have periodontal problems. However, with increasing age, the levels become higher reaching $78.1 \%$ and $92.1 \%$ in the age groups 35 44 and 65-74 years old, respectively ${ }^{3}$.

Gingivitis and periodontitis comprise the two major inflammatory diseases which affect the periodonto ${ }^{4}$, both being the result of an interactive process between dental plaque and periodontal tissues through cellular and vascular responses. The onset and progression of periodontal disease involve a number of immunopathological and inflammatory features, including local, systemic, environmental and genetic modifying factors ${ }^{5}$.

In the treatment of periodontal disease, like most chronic diseases, a strict control is required and considered of great importance for the improvement of oral health. This control aims to eliminate the etiologic factors, keeping the oral cavity free of bacteria by means of patient's plaque control and recurring dental prophylaxis programs, as well as promoting host defense through good physical and mental health ${ }^{4,6}$.

According to the World Health Organization recommendations ${ }^{7}$, all actions and practices devoted to health promotion should approach not only the disease but the patient as well, considering him an inseparable biopsycho-social being within society.
Thus, self-care and self- management are defined by the World Health Organization in its model of Care for Chronic Conditions as a behavior in which the individual acts autonomously in order to establish and maintain his health while preventing and dealing with the disease.

The patient, then, becomes knowledgeable about his own disease which helps him realize the importance of caring and actively manage his own health. Self-care produces greater compliance with therapeutic schemes, therefore reducing the risk of future complications and disability associated with chronic problems providing the patient with better life quality.

In periodontics, it is also acknowledged that the patient himself is usually more capable of controlling his health-related changes and lifestyle than the dental profissional ${ }^{6}$. To do so, he must be motivated. Motivation acts as a driving force in the prevention working as an inducing factor. Clinically, it means getting the patient's cooperation in order to lead him in the desired direction, i.e. a change in his behavior.

In this case, the communication between patient /dental practitioner is of crucial importance for a successful treatment. Dental professionals should induce the patient's attitudes toward obtaining periodontal health. Adding to that, the patient must understand that proper oral hygiene measures such as, diet care, alcohol and cigarettes moderation together with stress management can prevent disease progression. Moreover, a patient/dental professional shared responsibility for the treatment must be assumed by the patient while establishing his self-care routine ${ }^{6,8-9}$.

The perception of periodontal patients and their responsibility in controlling the disease has not been reported in our literature. Thus, the aim of this study is to assess, through a questionnaire, the patients' knowledge about the subject as well as the dental professionals' commitment to instruct their patients towards their behavior and perceptions concerning the importance of self-care in order to control periodontal disease.

\section{METHODS}

The target population for this study consisted of 50 patients who were under periodontical treatment in the dental clinics of the Periodontics graduate courses at São Leopoldo Mandic School, Campinas Campus, São 
Paulo. The research was initiated only after approval by the São Leopoldo Mandic Faculty Committee for Research Ethics under Protocol. 0241, with the patients' signature and free consent.

The sample consisted of male and female patients, age ranging between 30 and 70 years old and randomly selected from the waiting rooms of the institution. Patients who were starting treatment were excluded.

A questionnaire consisting of multiple choice questions was used as assessement tool and its content evaluated the patients' profile, their knowledge about periodontal disease and the dental professional's commitment to instruct the patients towards their behavior concerning oral hygiene along with their perception of the importance of self-care for disease control. Data was tabulated and submitted to exploratory analysis and analyzed through tables and graphs of frequency distribution.

\section{RESULTS}

The data from 50 questionnaires used a sample of $42 \%$ males and $58 \%$ female volunteers, mean age of 49.2 years old, ranging between 31 and 67 years. As far as socio-economic level is considered, most participants in the sample (58\%) reported a monthly income of up to 3 minimum wages, while $26 \%$ were found to be in the range between 4 and 7 minimum wages and 8\% 8-11 minimum wages.

Patient's behavior concerning oral hygiene was assessed through the questionnaire responses. Table 1 presents statements about frequency, duration and quality of brushing, as well as information about the kind of products used, as well as how daily oral hygiene instructions were integrated in their daily routines. Table 2 is concerned with the patient's knowledge about the periodontal disease and the dental professional's committment in promoting the necessary instructions.

Table 3 verifies the patient's perception as to the importance of self-care in order to control periodontal disease and the following variables were recorded: 1) Have you been following the dentist's the instructions? 2) Are you aware that if you follow the instructions correctly the dentist can contribute a lot to prevent the development of periodontal disease? The answers to these questions can be seen in Table 3.
Table 1. Patients's distribution considering their behavior towards oral hygiene.

\begin{tabular}{|c|c|c|}
\hline Questions/Answers & $\mathrm{n}$ & $\%$ \\
\hline \multicolumn{3}{|l|}{ How many times a day do you brush your teeth? } \\
\hline Once & 0 & 0,0 \\
\hline Twice & 8 & 16,0 \\
\hline Three times & 28 & 56,0 \\
\hline More than 3 times & 14 & 28,0 \\
\hline \multicolumn{3}{|l|}{$\begin{array}{l}\text { How long does it take you to perform a real perfect } \\
\text { brushing? }\end{array}$} \\
\hline Up to 2 minutes & 3 & 6,0 \\
\hline Between 3 and 6 minutes & 14 & 28,0 \\
\hline More than 6 minutes & 27 & 54,0 \\
\hline No responders & 6 & 12,0 \\
\hline \multicolumn{3}{|l|}{ Concerning your oral hygiene availability } \\
\hline I have all the time I need for a perfect brushing & 13 & 26,0 \\
\hline I have enough time for a good brushing & 17 & 34,0 \\
\hline I have little time but I try my best & 17 & 34,0 \\
\hline $\begin{array}{l}\text { I never have time, so I always do my brushing in a } \\
\text { hurry }\end{array}$ & 3 & 6,0 \\
\hline \multicolumn{3}{|l|}{ How do you grade your oral hygiene? } \\
\hline Excellent & 10 & 20,0 \\
\hline Very good & 20 & 40,0 \\
\hline Fair & 20 & 40,0 \\
\hline Bad & 0 & 0,0 \\
\hline \multicolumn{3}{|l|}{ Concerning your toothbrush } \\
\hline $\begin{array}{l}\text { Always uses the toothbrush type as recommended } \\
\text { by the dentist }\end{array}$ & 35 & 70,0 \\
\hline Likes to try different toothbrush types & 6 & 12 \\
\hline Preference for cheaper toothbrush types & 8 & 16,0 \\
\hline Prefers the most trendy toothbrush types & 1 & 2,0 \\
\hline
\end{tabular}

Among the products mentioned below, tick the one you are used to for oral hygiene ( the volunteer was allowed to more than one answer)

Floss

50100,0

interproximal toothbrush $\quad 2754,0$

End-tufted toothbrush $\quad 3366,0$

$\begin{array}{lll}\text { Antiseptic mouthwash solution } & 20 \quad 40,0\end{array}$

Do you attempt to integrate proper brushing techniques as part of your daily routine?

Yes, it has become a habit $\quad 41 \quad 82,0$

I still can't, but I keep trying $\quad 9 \quad 18,0$

It is very difficult for me $\quad 0 \quad 0,0$

Total of patients

$50 \quad 100,0$ 
Table 2. Patients' distribution according to variables related to the patient's knowledge about periodontal disease and the dental profissional's committment to instruct the patient.

\begin{tabular}{lcc}
\hline Questions/Answers & $\mathrm{n}$ & $\%$ \\
\hline $\begin{array}{l}\text { Dental biofilm build up on the tooth surface causes periodontal } \\
\text { disease }\end{array}$ & 2 & 4,0 \\
I do not know anything about this & 47 & 94.0 \\
My dentist has explained this to me & 1 & 2.0 \\
$\begin{array}{l}\text { I have learned on TV,magazines and } \\
\text { internet }\end{array}$ & &
\end{tabular}

Proper oral hygiene can control dental biofilm

I do not know anything about this

12,0

My dentist has explained this to me

$48 \quad 96.0$

! have learned this on TV,magazines and internet

12.0

When the periodontal disease is not treated, it can progressively cause tooth loss

I do not know anything about this

24,0

My dentist has explained this to me

$48 \quad 96,0$

I have learned on TV,magazines and

0

internet

My dentist has explained this to me

Do you consider having received proper periodontal disease information, from the dental professionals that have assisted you up to now?

Yes, they have explained everything to $32 \quad 64,0$
me

Yes, they have explained enough to me $17 \quad 34,0$

No, they could have explained much $\quad 1 \quad 2,0$ better to me

No, they have not explained anything to me

Were you able to understand well what the dental professionals explained to you about the disease?

$\begin{array}{lcc}\text { Yes } & 42 & 84,0 \\ \text { No } & 2 & 4,0 \\ \text { Some times } & 6 & 12\end{array}$

Have the dental professionals made use of visuals, flyers, movies to help your understanding?

$\begin{array}{lcc}\text { Yes } & 20 & 40,0 \\ \text { No } & 28 & 56,0 \\ \text { Some times } & 2 & 4,0\end{array}$

Table 3. Patients' distribution concerning the self-care variables in order to control periodontal disease.

\begin{tabular}{lcc}
\hline Questions/Answers & $\mathrm{n}$ & $\%$ \\
\hline Have you been following the dentist's instructions? & & \\
Yes & 41 & 82,0 \\
No & 0 & 0,0 \\
Some times & 7 & 14,0 \\
Did not provide answer & 2 & 4,0 \\
Are you aware that if you strictly follow the dentist's instructions \\
you can collaborate very much to avoid the periodontal disease \\
development? \\
Yes, I know \\
I don1t believe this \\
I have never thought about this & 100,0 \\
Total of patients & 0 & 0,0 \\
\hline
\end{tabular}

\section{DISCUSSION}

Preventing and controlling periodontal diseases are effective measures in order to avoid its development and ensure health maintenance not only of the teeth supporting tissues, but also the mouth and the individual as a whole, since periodontal diseases are associated with systemic conditions such as the difficulty of diabetes metabolic control, respiratory and cardiovascular diseases ${ }^{10-12}$.

The periodontal disease control through patient's active participation is a crucial feature for a successful treatment. Therefore, professionals expect them to promote a daily biofilm controlling routine by means of a suitable oral hygiene ${ }^{13}$.

The most effective method among prevention measures, is the one which considers the patients' active self- care so as to manage their own health and promote habit changes ${ }^{7}$. For this reason a questionnaire was applied to evaluate the responsiveness of the patient's self-care education and oral hygiene behavior.

As for toothbrushing frequency, it was found that $84 \%$ of the volunteers reported brushing at least 3 times a day. In relation to brushing time, the results were also positive, showing that $28 \%$ of the sample reporting that they performed brushing within a time ranging between 3 and 6 minutes, while $56 \%$ performed the procedure longer than six minutes. This demonstrates that these patients have satisfactory standards. Confirming this statement, $60 \%$ said they had enough time for a good brushing, and of these, $26 \%$ said they had all the necessary time to improve their brushing. 
According to Seyerskov ${ }^{14}$, more important than frequency is the hygiene quality. The data for self-assessment on the quality of hygiene was reported as excellent (20\%) or very good (40\%). Nobody reported a bad hygiene. On the whole it can be said that, for this sample of under treatment patients, they are striving to perform the biofilm control. Rylander and Lindhe ${ }^{15}$ emphasize that to generate appropriate oral hygiene habits, the patient's willingness and ability to clean his teeth properly is more important than the selection of a specific brushing method.

Regarding hygiene products, $70 \%$ of the volunteers reported using the brush recommended by the dentist. As for the use of dental floss, all 50 volunteers (100\%) reported an affirmative response, whereas 54\% of individuals make use of inter-proximal brush; $66 \%$ use end-tufted toothbrush and $40 \%$ use some antiseptic mouthwash solution.

The results showed that $82 \%$ of individuals had developed the proper brushing technique as a habit in their daily routine. This demonstrates that the majority of under treatment patients presenting periodontal disease, strive to acquire suitable products for daily biofilm control, despite their low socio-economic level (58\% of volunteers reported a monthly income of up to 3 minimum wages).

Such patient's good treatment responsiveness and dedication reflect dental professionals' instructions which are motivation-oriented. Petry \& Pretto $^{16}$ described that to motivate and promote behavioral changes in patients, it is necessary to follow a sequence of informative steps leading the patient to treatment commitment.

Essential information such as: biofilm accumulation on the tooth surface as the cause of periodontal disease; combining biofilm control with proper oral hygiene and tooth loss as a result of untreated periodontal disease, were considered of pristine importance for a under treatment patient. In the questionnaire, 94 to $96 \%$ of the patients reported that were informed about these items by the dental professionals, while 2 to $4 \%$ reported having learned about these through communication means.

The present study also showed that patients were aware about periodontal disease due to the high quality of information received. The data is as follows: $64 \%$ said the dental professional had explained everything and 34\% reported having received enough information.
As to understanding the instructions received, 84\% reported having understood all the dental professional's explanation, $12 \%$ only understood it partially and $4 \%$ could not aprehend the given information. According to Petry \& Pretto ${ }^{16}$, to facilitate learning it is necessary to use a clear, simple language appropriate to the age and cultural level of the patient.

Although the results were satisfactory, patients' better understanding of the instructions could improve if more visuals and flyers as well as illustrations were used to help. Bandler \& Grinder ${ }^{17}$ reported the importance of visual, auditory, kinesthetic, and olfactory and taste stimuli as essential aids for a patient's better understanding. Direct communication associated with the use of models, poster, leaflets and movies shows an efficient practice for motivating patients to oral hygiene and periodontal disease control 18 . However only $40 \%$ of volunteers reported receiving such aid for explanation. As perception of selfcare is concerned, a positive result was observed, since in the sample of 50 volunteers, $82 \%$ reported following the dental professionals' recommendations and even state to be aware that if they follow the instructions given they can collaborate to avoid progression of the periodontal disease. This seems to be the sum of many features as the knowledge of the disease etiology and pathology, treatment and control methods, as well as the motivational instructions by the dental professional. It can be clearly stated that the great majority of the patients was properly instructed for a healthy life.

\section{CONCLUSION}

It can be concluded, within the limitations of the present study, that the patient becomes motivated to promote his self-care and therefore control periodontal disease when proper motivation and instructions are enhanced by the dentist.

\section{Collaborators}

A GARCIA, EMA CLAVIJO, FM FLÓRIO, LS OKAJIMA and AS FONSECA-SILVA participated in all the stages of writing the article. 


\section{REFERENCES}

1. American Academy of Periodontology. Guidelines for the management of patients with periodontal diseases. J Periodontol. 2006;77(9):1607-11. doi: 10.1902/jop.2006.069001.

2. Barbato $P R$, Nagano HCM, Zanchet FN, Boing AF, Peres MA. Perdas dentárias e fatores sociais, demográficos e de serviços associados em adultos brasileiros: uma análise dos dados do Estudo Epidemiológico Nacional (Projeto SB Brasil 2002-2003). Cad Saúde Pública. 2007;23(8):1803-14. doi: 10.1590/S0102$311 \times 2007000800007$.

3. Brasil. Ministério da Saúde. Projeto SB Brasil 2003: condições de saúde bucal da População Brasileira 2002 -2003. Resultados principais. Brasília: Ministério da Saúde; 2005 [citado 2010 Ago 8]. Disponível em: < http://dtr2001.saude.gov.br/editora/ produtos/livros/pdf/05_0053_M.pdf>.

4. American Academy of Periodontology. Treatment of plaqueinduced gingivitis, chronic periodontitis, and other clinical conditions. J Periodontol 2001;72(12):1790-800. doi:10.1902/ jop.2001.72.12.1790

5. Sallum AW, Martins AG, Sallum EA. A doença periodontal e o surgimento de um novo paradigma. In: Brunetti MC. Periodontia médica: uma abordagem integrada. São Paulo: SENAC; 2004. p.21-39.

6. Genco JR, Goldman MH, Cohen DW. Periodontia contemporânea. São Paulo: Santos; 1996.

7. World Health Organization. Innovative care for chronic conditions: building blocks for action: global report. Geneva: World Health Organization; 2002 [cited 2010 Ago 8]. Available from: <http://www.who.int/chp/knowledge/publications/ icccreport/en/s.

8. Couto JL, Duarte CA. Comunicação e motivação em periodontia: bases para o tratamento odontológico. São Paulo: Editora Santos; 2006.

9. American Academy of Periodontology. Tobacco use and the periodontal patient. J Periodontol. 1999;70:1419-27.
10. Oppermann RV, Rosing CK. Prevenção e tratamento das doenças periodontais. In: Kriger L. ABOPREV: promoção de saúde bucal paradigma, ciência e humanização. $3^{\text {a }}$ ed. Rio de Janeiro: Artes Médicas; 2003. p.260-75.

11. Rose LF, Genco RJ, Mealey BL, Cohen DW. Medicina periodontal. São Paulo: Editora Santos; 2002.

12. Cury PR, Joly JC, Araújo VC, Wassall T, Araújo NS. Periodontite: fator de risco para doenças sistêmicas? RGO - Rev Gaúcha Odontol. 2003;51(4):210-4.

13. Lindhe J, Karring T, Lang, PN. Tratado de periodontia clínica e implantologia oral. $4^{a}$ ed. Rio de Janeiro: Guanabara Koogan; 2005.

14. Seyerskov ATO. Cariologia clínica. $2^{a}$ ed. São Paulo: Editora Santos; 1995.

15. Rylander $\mathrm{H}$, Lindhe J. Terapia periodontal associada à causa. In: Lindhe J. Tratado de periodontia clínica e implantologia oral. Rio de Janeiro: Guanabara Koogan; 1999. p. 314-31.

16. Petry PC, Pretto SM. Educação e motivação em saúde bucal In: Kriger L. ABOPREV: promoção de saúde bucal - paradigma, ciência e humanização. $3^{a}$ ed. Rio de Janeiro: Artes Médicas; 2003. p. 371-86.

17. Bandler R, Grinder J. Sapos em príncipes. São Paulo: Editorial Summos; 1982.

18. Couto JL, Couto RS, Duarte CA. A importância da comunicação na motivação de pacientes. RGO - Rev Gaúcha Odontol. 2003;51(5):401-6. 